\title{
Simulating fire patterns in heterogeneous landscapes
}

\author{
W.W. Hargrove ${ }^{a}$, R.H. Gardner ${ }^{\text {b,* }}$, M.G. Turner ${ }^{\mathrm{c}}$, W.H. Romme ${ }^{\mathrm{d}}$, \\ D.G. Despain ${ }^{\mathrm{e}}$ \\ ${ }^{a}$ Computational Physics and Engineering Division, Oak Ridge, National Laboratory Oak Ridge, Oak Ridge, TN 37830-6274, USA \\ b Appalachian Laboratory, University of Maryland, Center for Environmental Science, 301 Braddock Road, Frostburg, \\ MD 21532, USA \\ ${ }^{\mathrm{c}}$ Department of Zoology, Birge Hall, 430 Lincoln Drive, University of Wisconsin, Madison, WI 53706, USA \\ d Department of Biology, Fort Lewis College, Durango, CO 81301, USA \\ e National Park Service, Yellowstone National Park, WY 82190, USA
}

Received 13 December 1996; received in revised form 6 June 2000; accepted 14 July 2000

\begin{abstract}
A broad-scale probabilistic model of forest fires, EMBYR, has been developed to simulate the effects of large fires burning through heterogeneous landscapes. Fire ignition and spread are simulated on a gridded landscape by (1) examining each burning site at each time step, (2) independently evaluating the probability of spread to eight neighbors based on fuel type, fuel moisture, wind speed and direction, and (3) distributing firebrands to downwind sites, where the probability of ignition of new fires is a function of fuel type and moisture conditions. Low values for the probability of spread, $I$, produce a dendritic burn pattern resembling a slow, meandering fire, whereas higher values of $I$ produce solid patterns similar to a rapidly moving, intensely burning fire. $I$ had to be greater than a critical value, $i_{c}$, estimated to lie between 0.250 and 0.251 , to have a $50 \%$ chance of propagating across the landscape by adjacent spread alone. The rate of spread of fire at $I=0.30$ was nearly four times faster when firebrands were included in the simulations, and nearly eight times faster in the presence of moderate wind. Given the importance of firebrands in projecting fire spread, there is a need for better empirical information on fire spotting. A set of model parameters was developed to represent the weather conditions and fuel types on the subalpine plateau of Yellowstone National Park, WY, USA. Simulation experiments were performed to reveal relationships between fire and landscape-scale heterogeneity of fuels. In addition, EMBYR was used to explore fire patterns in the subalpine plateau by simulating four scenarios of weather and fuel conditions. The results of repeated simulations were compared by evaluating risk (the cumulative frequency distribution of the area burned) as a function of the change in weather conditions. Estimates of risk summarized the high degree of variability experienced in natural systems, the difficulty of predicting fire behavior when conditions are near critical thresholds, a quantification of uncertainties concerning future weather conditions, and useful tool for assessing potential wildfire effects. (C) 2000 Elsevier Science B.V. All rights reserved.
\end{abstract}

Keywords: Fire model, fire effects, cellular automaton; EMBYR; Landscape model; Patch formation; Pattern; Simulation; Wildfire; Yellowstone National Park

\footnotetext{
* Corresponding author. Tel.: + 1-301-6897125; fax: + 1-301-6897200

E-mail address: gardner@al.umces.edu (R.H. Gardner).
} 


\section{Introduction}

Landscape-scale fire patterns result from complex interactions among weather, ignition, vegetation type, fuel moisture, and topography. Many models that simulate fire spread are based on thermodynamic principles that require detailed information on local wind speed, topography, relative humidity, fuel moisture, and the structure and packing of the fuel bed (e.g. Rothermel, 1972, 1983; Albini, 1976; Kessell, 1976; Van Wagner, 1977; Burgan and Rothermel, 1984; Albini and Stocks, 1986; Izbecki and Keane, 1989). Kessell (1979), and more recently Vasconcelos and Guertin (1992), have adapted the Rothermel (1972) and Rothermel (1983) thermodynamic model to consider the spatial heterogeneity of fuels across a landscape. Since these models are designed to predict the localized spread of ground fires over limited time scales (i.e. a few hours), their utility for projecting broad-scale spatial patterns of large fires over longer time periods remains problematic. Another promising approach is that of fire wave models (i.e. Finney, 1993; Keane et al., 1996a,b), which combine thermodynamically-based point estimates of equilibrium forward spread rate with analytical solutions for the propagation of elliptically-shaped fire perimeters (Richards, 1993). Wave-type fire models are computationally intensive (Keane et al., 1996a,b) and are greatly complicated by heterogeneous arrangement of fuel within landscapes and local variation in weather conditions (Finney, 1993, 1999).

In a review of fire models Gardner et al. (1999) determined that few models are capable of simulating fire effects at broad spatial scales. The most efficient simulators are models based on empirically estimated probabilities of fire starts and spread (e.g. Van Wagner, 1969; MacKay and Jan, 1984; Albinet et al., 1986; Baker, et al., 1991; Antonovski et al., 1992; Baker, 1993). Spatially explicit probabilistic models have also been used to explore the effects of landscape structure on propagation and pattern of disturbance (Turner et al., 1989; Gardner and O’Neill, 1991; Turner and Dale, 1991) and the conditions under which a fire spreading through a simple, homogeneous, two- dimensional space become 'critical', i.e. can spread from one end of the space to the other (Albinet et al., 1986; Hirabayashi and Kasahara, 1987). In contrast to fine-scale thermodynamic fire models, probabilistic models usually do not predict daily fire spread (but see Clarke et al., 1993, 1994), but attempt to characterize the broad-scale heterogeneity and final pattern of burn (e.g. Andersen, 1983; Green, 1983).

Most probabilistic models of fire spread predict the rate of spread under isotropic, no-wind conditions in a continuous, homogeneous fuel layer (i.e. Kourtz and O'Regan, 1971). Some models employ biased probabilities to simulate wind effects on fire spread, but only consider a homogeneous fuel layer (O'Regan et al., 1976; Ohtsuki and Keyes, 1986; Nahmias et al., 1989). A model constructed by von Niessen and Blumen (1988) combined unbiased and biased probabilities of fire spread through two stacked non-uniform layers of fuel types to represent differences in dynamics of surface and crown fires.

A model by Baker et al. (1991) predicts landscape patterns by selecting maximum fire sizes from empirical reconstructions of fire sizes for different synoptic weather conditions, allowing the disturbance to spread to the eight adjacent neighbors until the maximum size is reached or all available sites have been disturbed. However, weather and wind do not directly affect the pattern of spread (Baker et al., 1991; Baker, 1993). Green et al. (1990) and Clarke et al. (1993, 1994) include effects of wind, fuel moisture, and slope, but firebrands are not included, and the time frame for simulation of fire effects is short (e.g. days). Antonovski et al. (1992) consider the broad-scale heterogeneity of fuels and their regrowth after fire, but the time step is coarse (1 year) and simulations do not include the influence of wind or firebrands on fire pattern.

Predicting the ecological effects of landscapescale fires requires a spatially explicit fire model capable of simulating the long-term dynamics of disturbance-prone landscapes (Green, 1989; Turner et al., 1989, 1994; Gardner et al., 1999). The model must operate at a grain size that is fine enough to adequately characterize the local variability in fuels, but still predict fire spread at 
broad spatial scales. The effect of fuel moisture and wind on fire ignition and spread must be incorporated in the model, and the role of firebrands on fire pattern and spread should also be included. Finally, model execution should be efficient and relatively inexpensive so that the many factors affecting the patterns of fire at landscape scales can be evaluated. Several models have been developed that have some, but not all, of these features.

This paper presents a spatially explicit probabilistic model of large fires that incorporates effects of landscape-scale variation in fuel type, weather conditions which affect fuel moisture, variable wind speed and direction, and the effect of firebrands on the spread and spatial pattern of crown fires. We first explore the effects of wind speed, wind direction, and firebrands on the spread and spatial pattern of fires within a homogeneous landscape. The model is used to simulate fire spread in an actual landscape under several fuel moisture conditions, with the results of different stochastic simulations expressed as frequency distributions of area burned as a consequence of fuel moisture, wind and landscape heterogeneity. The concept of critical densities of combustible fuels is presented, with probabilistic results expressed as risk of area burned under alternative weather scenarios. The uncertainties associated with risk estimates are evaluated and the data requirements for estimating parameters and verifying predictions of landscape-scale fires are discussed.

\section{The fire model}

The fire model, EMBYR, depicts the landscape as a grid in which the dimension of each cell is 50 $\mathrm{m}\left(2500 \mathrm{~m}^{2}\right)$. Single or multiple ignitions can occur randomly or by specifying the coordinates of the ignited cells. A number of processes that affect the landscape patterns of fire spread are considered, including diffusive spread from cell to cell, the impact of wind speed and direction, ignition of distant cells by firebrands, and changes in the combustibility of different fuel types due to variation in fuel moisture. The model is written in
Fortran 77 and executes in a UNIX/LINUX environment, and accepts and produces data files compatible with a variety of GIS software. Documentation, source code, executables and example simulations can be found at http:// www.al.umces.edu/download-gardner.html.

\subsection{Simulating diffusive spread}

Fire spreads from each ignited cell to any of eight unburned neighbors (the four adjacent cells and four diagonal cells) as an independent stochastic event with probability $I$, where $I$ may range from 0 to 1 . Each cell burns for a single time step of variable length, and the fire goes out if new sites are not ignited at each time step. Theoretical studies have demonstrated that if $I$ is less then a critical value, $i_{c}$, fires are unlikely to propagate across the landscape (Grassberger, 1985; Stauffer and Aharony, 1992). The numerical value of this critical threshold is a function of the number of neighbors and the rule used to determine spread to these neighbors within a given time step (e.g. bond versus site percolation, Plotnick and Gardner, 1993). The independent evaluation of spread to eight neighboring cells employed by EMBYR is a bond percolation process (Stauffer and Aharony, 1992) with a critical threshold that has not been previously defined (Plotnick and Gardner, 1993). We estimated $i_{c}$ by performing 50 simulations for each value of $I(0.245 \leq I \leq 0.252$ in increments of 0.001$)$ on a $300 \times 300$ grid and calculated the percent of the simulations in which the fire reached the opposite edge of the map. The proportion of simulations with fires reaching the top edge of the map after the entire bottom edge was ignited was $38 \%$ for $I=0.250$ and $60 \%$ for $I=0.251$. Since $i_{c}$ is the threshold at which $50 \%$ of the fires reach the opposite edge of the map, these results indicated that $i_{c}$ lies between 0.250 and 0.251 .

One might expect that the probability of spread in diagonal directions should be adjusted to compensate for the greater distance from the burning cell to each of its four diagonal neighbors. Fig. 1 illustrates burn patterns produced by EMBYR without wind or firebrands for values of $I$ ranging from 0.25 (the critical threshold) to 0.6 (the upper 
range of values of $I$ used in the model for very dry, windy conditions). Simulated fire patterns were not affected by the square grid geometry until $I$ approaches the upper limit of 0.6. Corrections for increased diagonal distance did produce rounded patterns for values of $I \geq 0.6$, but the same corrections resulted in patterns biased in the cardinal directions for $I$ ranging from 0.25 to 0.5 , the range most important for our simulations. Therefore, the probability of movement to diagonal neighbors is not adjusted in EMBYR.

The most important factor in determining the shape of simulated fire fronts for values of $I$ from 0.25 to 0.5 was not the distance to unburned cells, but rather the number of adjacent burning neighbors next to an unburned cell. Imagine that a $3 \times 3$ block of cells has been ignited. An unburned cell diagonally off the corner of this burning block will have only one burning neighbor to potentially ignite it. On the other hand, an unburned cell lying directly adjacent to the straight edge of the burning front will have three neighbors that could potentially ignite it. Thus, cells along the middle sections of straight edges experience an increased likelihood of ignition over unburned cells at the ends of straight edges or along diagonals. This effect encouraged curved fire fronts over straight ones, resulting in the patterns shown in Fig. 1(ac).

However when $I$ was large, the probability of spread in diagonal directions approached that for spread along the advancing front, and the pattern began to be affected by the square geometry of the grid (Fig. 1d). At the extreme of $I=1$, all

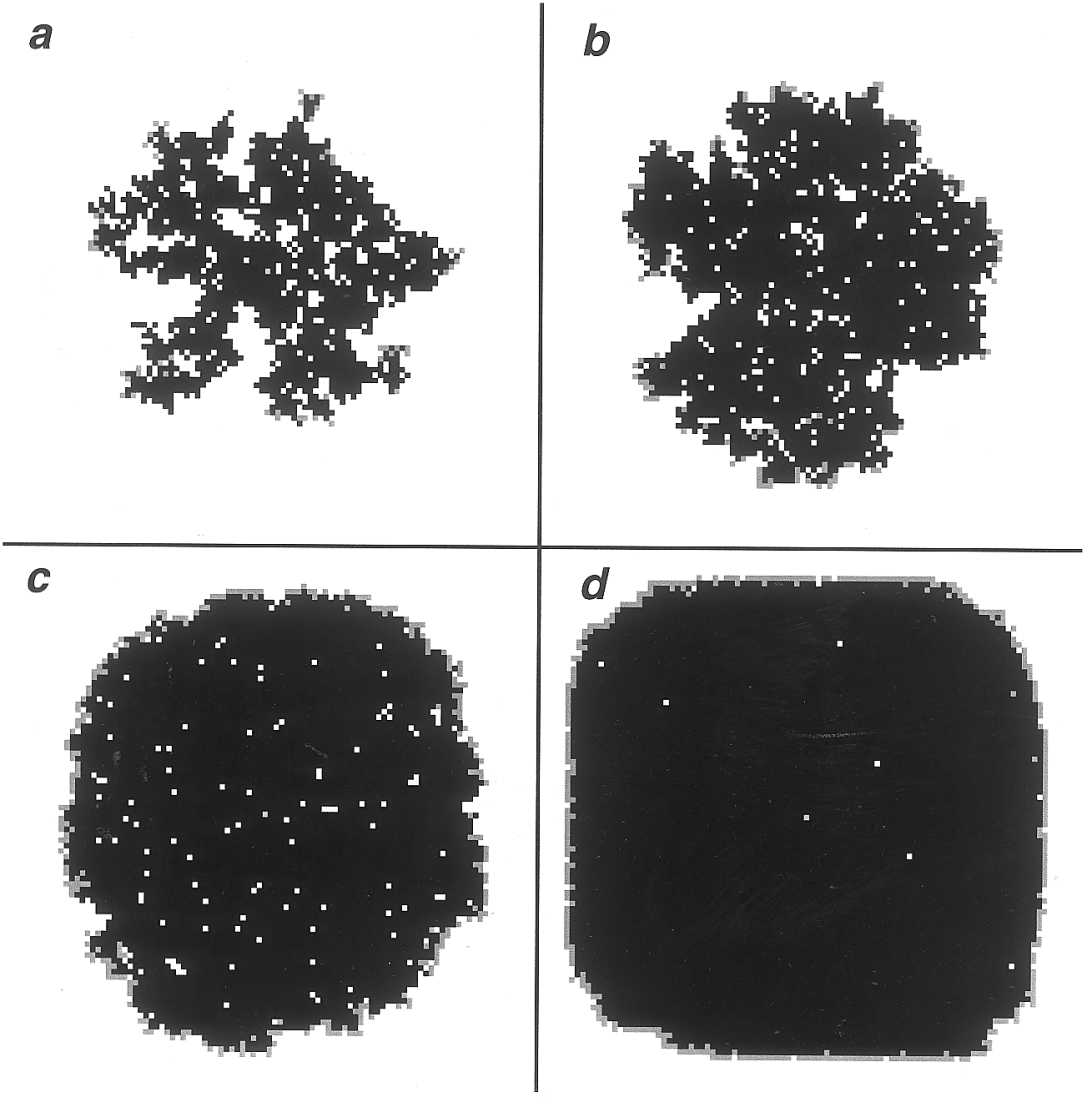

Fig. 1. Pattern of burning produced after 100 time steps by different values of $I$ in homogeneous $200 \times 200$ gridded landscape without wind or firebrands. (a) $I=0.25$, (b) $I=0.3$, (c) $I=0.4$, and (d) $I=0.6$. White sites are unburned, black sites are burned, and gray indicates sites currently burning. 
Table 1

Estimated probability, $I$, of fire spread at landscape scales ${ }^{\mathrm{a}}$

Fuel moisture class 1

\begin{tabular}{llllll}
\hline LP0 & 0.1 & 0.15 & 0.2 & 0.25 & 0.15 \\
LP1 & 0.1 & 0.2 & 0.25 & 0.3 & 0.2 \\
LP2 & 0.1 & 0.2 & 0.3 & 0.35 & 0.2 \\
LP3 & 0.1 & 0.2 & 0.3 & 0.4 & 0.2 \\
NF & 0.1 & 0.2 & 0.25 & 0.3 & 0.2
\end{tabular}

Fuel moisture class 2

$\begin{array}{llllll}\text { LP0 } & 0.06 & 0.07 & 0.1 & 0.16 & 0.65 \\ \text { LP1 } & 0.06 & 0.08 & 0.11 & 0.17 & 0.07 \\ \text { LP2 } & 0.06 & 0.08 & 0.15 & 0.2 & 0.07 \\ \text { LP3 } & 0.06 & 0.08 & 0.15 & 0.26 & 0.07 \\ \text { NF } & 0.06 & 0.07 & 0.11 & 0.16 & 0.07\end{array}$

Fuel moisture class 3

$\begin{array}{llllll}\text { LP0 } & 0.01 & 0.03 & 0.04 & 0.06 & 0.01 \\ \text { LP1 } & 0.01 & 0.04 & 0.06 & 0.07 & 0.02 \\ \text { LP2 } & 0.01 & 0.04 & 0.07 & 0.09 & 0.02 \\ \text { LP3 } & 0.01 & 0.04 & 0.07 & 0.1 & 0.02 \\ \text { NF } & 0.01 & 0.03 & 0.04 & 0.06 & 0.02\end{array}$

\begin{abstract}
a The matrix contains the probability of spread from every fuel type to every other fuel type for three fuel moisture classes. Columns represent fuel type that is presently burning, and rows represent fuel type of the adjacent unburned cell. The diagonal elements represent propagation within a single fuel type. Above-diagonal values are transfers from more combustible to less combustible fuel types, and below-diagonals are the converse. LP0, LP1, LP2 and LP3 are successional stages of lodgepole pine and NF is non-forested sites (see text for details). The fuel moisture classes describe 1000-h time lag fuel moisture conditions (see text for details). Fuels with $<12 \%, 12-16 \%$ and $>16 \%$ fuel moisture belong to class 1,2 and 3 , respectively.
\end{abstract}

unburned neighbors would be ignited, the fire pattern would be perfectly square, and the number of burning neighbors would be of no consequence. The number of burning neighbors is increasingly important as $I$ decreases. This same donor-based logic explains why more internal unburned cells remained within the perimeters of fires burning at low $I$ values (e.g. Fig. 1b) than those burning at high values of $I$ (Fig. 1d). Over most of the range of $I$ values used in the model, the effect of the additional distance to diagonal neighbors was offset by the nature of the rules governing adjacent spread.

Meakin (1986) has shown through extensive simulations that the underlying geometry of the square grid may become apparent if enough events (i.e. $>10^{8}$ sites burned) are simulated. However, the largest fires that we simulate are far smaller than this criterion, so effects of grid geometry are apparent only when the fire is limited to a single burned cell, or when $I \geq 0.6$. Fortunately, all model behavior of interest occurs between these extremes.

\subsection{Simulating multiple fuel classes}

EMBYR explicitly simulates multiple classes of fuel by varying the probability of fire spread (Table 1) as a function of fuel type. The simulations reported here consider six fuel classes based on vegetation in the subalpine plateau of Yellowstone National Park (YNP), Wyoming, USA. The fuel classes considered are four successional stages of lodgepole pine (Pinus contorta Doug. ex Loud. var. latifolia Engelm. ex Wats.) forest, nonforested regions such as meadows, and nonflammable areas such as rock, roads, and water.

The four successional stages of lodgepole pine vary substantially in fuel characteristics (Despain, 1977, 1990). The youngest stage, referred to as LP0, represents recently burned forests that generally are less than 40 years old with lodgepole pine well-established at the site, but the canopy not yet closed. Fuels consist primarily of forbs, grasses, standing snags and fallen logs. The next stage, LP1, extends from canopy closure to maturation of the lodgepole pine that form the canopy, generally from 40 to 150 years post fire. There is minimal understory, forest floor vegetation is sparse, and there is little dead woody material in most stands. The LP2 stage is composed of stands that are 150-250 year old with a continuous closed-canopy overstory of lodgepole pine. An understory of Engelmann spruce (Picea engelmannii Parry ex Engelm.), subalpine fir (Abies lasiocarpa [Hook.] Nutt.) and/or lodgepole pine 2-3 m in height may develop late in this stage. There is typically a thick layer of herbaceous and shrubby vegetation on the forest floor, but dead woody material still is sparse. Finally, the LP3 stage includes stands that are generally greater than 250 years old in which substantial mortality has occurred in the lodgepole pine canopy. The canopy is broken and uneven and the understory is well- 
developed with lodgepole pine, subalpine fir, and Engelmann spruce of many size classes. Deep litter, and a large mass of dead-and-down fuels cover the ground, and a continuous 'ladder' of green vegetation connects the surface and crown fuels.

Multiple fuel classes require the estimation of probabilities of spread between each pair of fuel classes. The flammability of lodgepole stands in YNP appears to increase with succession, and there is an important interaction with weather conditions. Between 1972 and 1987, a period which included average to moderately severe fire seasons, 235 lightning-caused fires were closely monitored by allowing them to burn without interference in YNP. These fires were significantly more likely to begin in older stands (LP3) than younger stands, and the area burned within LP3 stands was greater than predicted from a simple ratio of stand ages (Despain, 1990). Younger stands did not burn readily, even under moderately dry conditions, evidently because the mass and spatial arrangement of fuels were not conducive to fire spread (Despain, 1990; Renkin and Despain, 1991). These empirical data, combined with extensive observation of fire behavior and burn patterns by one of us (D.G. Despain) and an understanding of the percolation dynamics of grid-based models, resulted in the creation of a table of spread probabilities among fuel classes under moderately dry conditions (Table 1, fuel moisture class 2). These parameters represented our 'best guess' or 'expert opinion' concerning probabilities of spread for the subalpine plateau of YNP.

\subsection{Variation in fuel moisture}

To track fuel moisture, EMBYR uses a standard fire danger measure known as percent 1000$\mathrm{h}$ time-lagged fuel moisture (Fosberg and Deeming, 1971). In this measure, an assumption is made about how long fuel of a particular diameter would take to soak to the core, or to dry out once soaked. Then, current internal moisture in fuels of that diameter is modeled with appropriately time-lagged ambient atmospheric humidity. A 1000-h time lag for atmospheric humidity ap- propriately models fuel moisture in $20 \mathrm{~cm}$ diameter dead fallen logs (Fosberg and Deeming, 1971).

Obviously, if fuels are sufficiently wet, fires do not occur. In YNP from 1972 to 1987, fires never burned more than 10 ha when 1000-h time-lagged fuel moisture exceeded 16\% (Renkin and Despain, 1991). As conditions became drier (1000-h fuels with $12-16 \%$ moisture), the sites with heavy and continuous fuels (LP3) became highly susceptible to fire. Large increases in the amount of area burned in YNP occurred when the 1000-h timelagged fuels dropped below $12 \%$ moisture, and all successional stages became susceptible to burning (Renkin and Despain, 1991).

These empirical relationships were used to estimate probabilities of fire spread within and across fuel types for three fuel moisture classes that represent a range of summer weather conditions in YNP. The three fuel moisture classes approximate burning conditions when 1000-h time lag fuels are very dry $(<12 \%)$, moderately dry $(12-$ $16 \%$ ), and moist $(>16 \%)$. Consideration of fire spread through 5 fuel types under 3 different fuel moisture classes requires the estimation of $5 \times$ $5 \times 3=75$ transfer probabilities (Table 1). The elements of the matrix are the $I$ values and represent, within any moisture class, the probability of spread from one fuel type (column) to another fuel type (rows), with the diagonal elements indicating probabilities of spread within a single fuel type.

Qualitative estimates for the diagonal elements of the matrix for each fuel moisture class were made by determining which fuel types historically propagate fires at YNP (i.e. the value $I$ would be above $i_{c}$ ). Values above and below $i_{c}$ were adjusted to produce patterns of spread within homogeneous fuels that resembled observed patterns (higher values of $I$ produce more solid burn patterns). The off-diagonal elements of the matrix have a limited effect on the broad- scale patterns of fire effects. These elements affect spread between, but not within a given fuel type. The average size of even-aged stands at YNP is much larger than the 50-m cell size, making simulation results relatively insensitive to the estimates of these off-diagonal elements. Values for the off-diagonal elements were estimated by a weighted 
average of the respective diagonal elements, with the assumption that hotter burning fuels were more likely to ignite cooler burning fuels than the converse. For instance, homogeneous LP3 stands will burn more readily $(I=0.4)$ than stands of LP1 $(I=0.2)$ when fuels are very dry (fuel moisture class 1). Therefore, we estimated LP3-LP1 ignition at 0.3 while the LP1-LP3 estimate is 0.2 .

\subsection{Simulating the effects of wind}

Three classes of wind speeds (WS), measured at a standard height of $6.1 \mathrm{~m}(20 \mathrm{ft})$ above the surface, are considered: WS 0 , with speeds ranging from 0 to $3.1 \mathrm{kph}(5 \mathrm{mph})$; WS 1 , moderate winds ranging from 3.1 to $21.7 \mathrm{kph}(5-35 \mathrm{mph})$; and WS 2, strong wind with speeds greater than $21.7 \mathrm{kph}$. For each of the three wind speed classes, a bias value $b$ is used to modify the probability of spread to each neighboring cell (Fig. 2). There is no wind effect for WS 0, so all bias values are 1.0. Higher wind speeds of WS 1 and WS 2 progressively increase the likelihood of fire spread to downwind sites (Fig. 2).

The bias values, $b_{\mathrm{j}}$, are used to modify $I$ to produce a wind-corrected directional probability of fire spread, $i_{w j}$, in the $j$ th direction $(j=1,8)$. The adjustment is a cumulative binomial probability: $i_{w j}=1-(1.0-I)^{b_{j}}$, where $b_{j}$ is the appropriate directional bias factor obtained from a matrix of the eight possible relative wind direc-

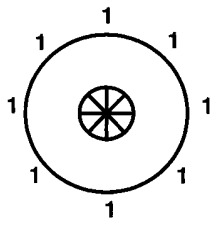

WS 0

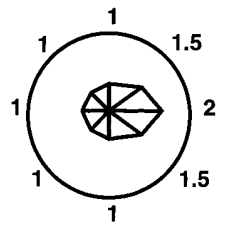

WS 1

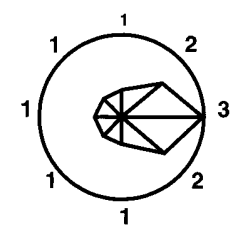

WS 2
Fig. 2. Circular plots of directional bias factors used to simulate wind direction effects under no wind (WS $0,<3.1$ $\mathrm{kph}$ ), moderate wind (WS 1, 3.1-21.7 kph), and strong wind (WS 2, > $21.7 \mathrm{kph}$ ). Arrow indicates wind direction. For WS 0 , all bias factors are 1.0 (no bias). Wind can be simulated from any of the eight directions by rotating the matrix of bias factors until the greatest bias is downwind. tions (Fig. 2). The position of the adjacent unburned cell relative to the burning cell and the wind direction determines which bias factor is used. When there is no wind, $b=1$, and $i_{w j}=I$. The effect of the wind bias terms is illustrated by assuming that the climatic conditions are 'very dry' and the no-wind transfer probability to a cell immediately east of a burning cell $I$ is 0.4 . If the wind is blowing toward the east and wind speeds fall in the range of WS $1(3.1-21.7 \mathrm{kph})$ then the easterly neighbor $(j=4)$ is twice as likely to be ignited by the fire $\left(b_{4}=2.0\right.$, Fig. 2$)$, and, from the binomial, $i_{w 4}=1-(1-0.4)^{2}=0.64$. Similarly, if a WS 2 wind is blowing, then $b_{4}=3.0$, and $i_{w 4}=$ $1-(1-0.4)^{3}=0.78$. Values for the bias terms were estimated by reviewing historical records of fire spread and wind conditions in YNP, and represent a consensus among the Yellowstone fire managers (P. Perkins, pers. commun.).

\subsection{Simulating the effects of firebrands}

EMBYR simulates a second mechanism of fire spread - the production of firebrands which are carried aloft in the rising convection column, and then drift and fall on remote sites. The 'spotting' effect of firebrands is simulated by permitting each burning site to generate a fixed number of firebrands as a function of fuel type (Table 2). The paucity of data on numbers and effects of firebrands produced by various forest fuels made empirical estimation of firebrand parameters difficult. The SPOT subroutine of the Rothermelderived BEHAVE fire prediction model (Andrews and Chase, 1989) was used to estimate maximum spotting distances from wind-driven surface fires for each of the three wind speed classes considered in EMBYR (Table 2). The maximum distance traveled by firebrands generated by SPOT was assumed to represent the 99th percentile of a negative exponential distribution. The mean of this negative exponential function was $150 \mathrm{~m}$ (three cells) for WS 0 condition, $250 \mathrm{~m}$ (five cells) under WS 1 and $300 \mathrm{~m}$ (six cells) for WS 2 .

Firebrands were assumed to be distributed in random directions for WS 0 , but traveled downwind in a $3^{\circ}$ normal random angle around the prevailing wind direction in WS 1 and 2. When a 
Table 2

Generation of firebrands by fuel type and the probability of ignition in unburned sites

\begin{tabular}{|c|c|c|c|c|c|}
\hline LP0 & LP1 & LP2 & LP3 & NF & \\
\hline \multicolumn{6}{|c|}{ Number of firebrands by fuel type $\mathrm{a}^{\mathrm{a}}$} \\
\hline 0 & 1 & 4 & 8 & 0 & \\
\hline \multicolumn{6}{|c|}{ Firebrand ignition probability for each fuel type $\mathrm{e}^{\mathrm{a}}$} \\
\hline Fuel moisture class ${ }^{\mathrm{b}}$ & LP0 & LP1 & LP2 & LP3 & $\mathrm{NF}$ \\
\hline 1 & 0.005 & 0.02 & 0.05 & 0.1 & 0.005 \\
\hline 2 & 0.003 & 0.01 & 0.02 & 0.05 & 0.003 \\
\hline 3 & 0.001 & 0.005 & 0.008 & 0.01 & 0.001 \\
\hline
\end{tabular}

\footnotetext{
${ }^{\text {a }}$ LP0, LP1, LP2 and LP3 are increasingly flammable successional stages of lodgepole pine, and NF are non-forested sites (see text for details).

b The fuel moisture classes describe 1000-h time lag fuel moisture conditions (see text for details). Fuels with $<12 \%, 12-16 \%$ and $>16 \%$ fuel moisture belong to class 1,2 and 3 , respectively.
}

firebrand lands on an unburned site, an ignition probability (Table 2), based on the fuel moisture condition and the fuel type on which the firebrand has landed, is used to stochastically determine whether the firebrand causes a new fire to start. Since very little information exists for estimating parameters describing this process, we assumed (1) that the order of ignition probabilities would be: $\mathrm{NF}=\mathrm{LP} 0<\mathrm{LP} 1<\mathrm{LP} 2<\mathrm{LP} 3$, (2) that the effect of different weather conditions on the probability of ignition would be: very dry $>$ dry $>$ moist, and (3) that there is a one in ten chance of igniting an LP3 site with a single firebrand under very dry weather conditions. These assumptions allowed an arbitrary but consistent set of parameters to be estimated (Table 2).

Production of firebrands varied among the successional stages because of differences in vegetation structure. LP3 stands with a continuous fuel ladder may have the greatest availability of optimum firebrand material. To simulate fire in a heterogeneous landscape, we assumed that the number of firebrands produced increases with the successional stage of the site (Table 2).

In summary, EMBYR uses a hierarchical process for modifying transfer probabilities to stochastically simulate wildfires in heterogeneous landscapes. This procedure is (1) each burning site is examined at each time step and the fuel types of the eight neighbors are determined, (2) the transfer probabilities ( $I$ values) for current weather conditions are obtained from Table 1, (3) the probabilities are adjusted by the wind bias factor, (4) spread to each neighbor is independently determined by generating uniform random numbers between 0 and 1 , with fire spread to that neighbor occurring if the value is less than the wind-corrected transfer probability, (5) firebrands are distributed according to the fuel class and wind conditions, (6) ignition of new sites by firebrands is randomly determined with probabilities as shown in Table 2, and (7) sites burning in the previous time step are extinguished.

\section{Simulation results}

\subsection{Simulations in homogeneous landscapes}

The effect of different values of $I$ on fire pattern as a result of diffusive spread was evaluated by a series of simulations on a $500 \times 500$ gridded landscape of homogeneous fuel (i.e. an even-aged forest). A single fire was started in the center of the map, and the simulation was stopped after forty time steps. Since the map was large (62 500 ha), fires never reached the edge of the map. Each simulation was replicated five times for values of $I$ ranging from 0.10 to 0.60 . For values of $I$ below the critical threshold, fires quickly went out (Fig. 3a, lowest curve). As $I$ increased above $i_{c}$, the area burned increased (Fig. 3a). Variance in area 
burned increased to a maximum near $I=0.40$, because some replicates failed to progress beyond the single-cell ignition point. When we used a smaller $300 \times 300$ cell landscape, and stopped the simulation when fire reaches the edge of the grid, mean time to edge decreased with increasing $I$ (Table 3). At large values of $I$, the number of burning cells increased through time in a nearly deterministic way with little variance.

Edges of burned areas were estimated on a per cell basis by evaluating all the eight neighbors. The number of edges per cell, which ranged between 0 and 8 , was greatest at $I=0.30$, and decreased with greater values of $I$ (Table 3 ). These edges resulted from both internal, embedded gaps

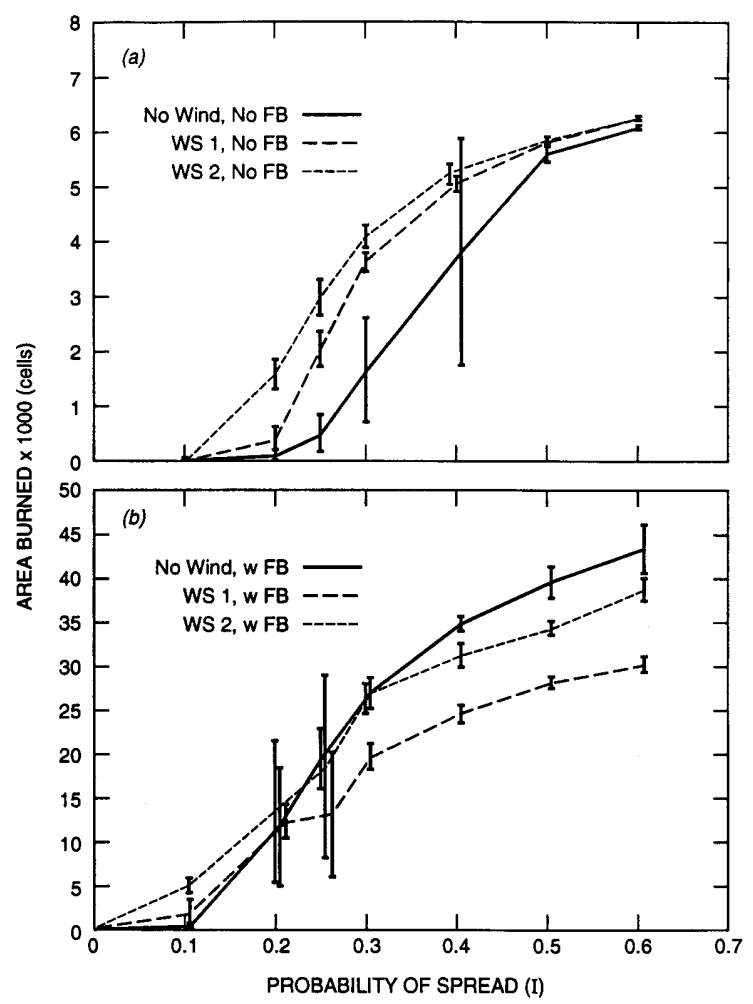

Fig. 3. Area burned (in cells) in a $500 \times 500$ cell homogeneous fuel class landscape with a single fixed ignition as a function of the probability of fire spread, I, to the eight surrounding neighbors where (a) fire is allowed to propagate by adjacent spread only (no firebrands), and (b) fire is allowed to propagate by adjacent spread and by firebrands. The simulation was ended before fire could reach the edge of the map. Means and standard deviations are shown for five replications.
Table 3

Fire pattern statistics under different values of $I$ in a $300 \times 300$ cell homogeneous fuel layer with a single ignition in the center of the map ${ }^{\mathrm{a}}$

\begin{tabular}{lcc}
\hline Variable $^{\mathrm{b}}$ & Mean & $\mathrm{CV}$ \\
\hline$I=0.30^{\mathrm{a}}$ & & \\
Total burned & 54888.0 & 2.57 \\
Time to edge & 174.0 & 2.84 \\
Edge/cell & 0.74 & \\
$I=0.40^{\mathrm{a}}$ & & \\
Total burned & 864.2 & 0.80 \\
Time to edge & 150.8 & \\
Edge/cell & 0.22 & \\
$I=0.50^{\mathrm{a}}$ & 80396.2 & 0.81 \\
Total burned & 149.2 & 0.30 \\
Time to edge & 0.08 & \\
Edge/cell & & \\
\hline
\end{tabular}

a There is no wind and only adjacent spread is simulated (no firebrands). Simulations were stopped when the fire reached the edge of the map. Summary statistics are for five replications. Units are in $50 \times 50 \mathrm{~m}$ cells $(0.25 \mathrm{ha}) ; I=$ unbiased probability of fire spread from an ignited cell to one of eight unburned neighbors, where $0 \leq I \leq 1$.

$\mathrm{b}$ The variables are: total burned - the total number of cells burned per simulation, Time to edge - the number of steps required for the fire to reach the edge of the map, edge/cell — the average edge per burned cell (see text for details).

where the fire failed to burn all available fuel, and from the additional length of a more finely digitate perimeter at the fire front. Lower values of $I$ suggested a meandering fire with a dendritic burn pattern, whereas higher values produced solid patterns similar to a rapidly moving, intensely burning fire.

The addition of wind from a fixed direction marginally increased the area burned at large $I$ values, but significantly affected fire spread for low values of $I$ (Fig. 3a, upper two curves). The reason is that when $I$ is below $i_{c}$ the wind bias terms can raise the probability of spread, $i_{w j}$, above the critical threshold. For instance, if $I=$ 0.2 and $b_{j}=2.0$ then $i_{w j}$, the local probability of spread, will equal $1.0-(1.0-0.2) 2=0.36-\mathrm{a}$ value well above the critical threshold of 0.251 . Wind also changed the spatial pattern of burning, constraining it to the downwind direction. Increasing wind speed resulted in smaller increases in area burned with increasing $I$. The amount of 
Table 4

Fire pattern statistics under different values of $I$ in a $300 \times 300$ cell homogeneous fuel layer with a single ignition in the center of the map ${ }^{\mathrm{a}}$

\begin{tabular}{|c|c|c|}
\hline Variable $^{\mathrm{b}}$ & Mean & $\mathrm{CV}$ \\
\hline \multicolumn{3}{|l|}{$W S=0, I=0.3^{\mathrm{a}}$} \\
\hline Total burned & 44290.2 & 11.39 \\
\hline No. patches & 147.2 & 9.40 \\
\hline$S_{\mathrm{av}}$ & 43372.9 & 11.24 \\
\hline Time to edge & 47.4 & 5.91 \\
\hline Edge/cell & 0.52 & \\
\hline \multicolumn{3}{|l|}{$W S=0, I=0.4^{\mathrm{a}}$} \\
\hline Total burned & 42881.8 & 10.01 \\
\hline No. patches & 124.4 & 16.22 \\
\hline$S_{\mathrm{av}}$ & 42089.8 & 9.51 \\
\hline Time to edge & 40.0 & 5.25 \\
\hline Edge/cell & 0.29 & \\
\hline \multicolumn{3}{|l|}{$W S=0, I=0.5^{\mathrm{a}}$} \\
\hline Total burned & 50230.4 & 3.64 \\
\hline No. patches & 115.8 & 9.70 \\
\hline$S_{\mathrm{av}}$ & 49436.2 & 3.90 \\
\hline Time to edge & 39.4 & 6.35 \\
\hline Edge/cell & 0.19 & \\
\hline \multicolumn{3}{|l|}{$W S=1, I=0.3^{\mathrm{a}}$} \\
\hline Total burned & 6012.6 & 17.54 \\
\hline No. patches & 17.4 & 14.98 \\
\hline$S_{\mathrm{av}}$ & 5886.3 & 18.33 \\
\hline Time to edge & 23.0 & 10.00 \\
\hline Edge/cell & 0.54 & \\
\hline \multicolumn{3}{|l|}{$W S=1, I=0.4^{\mathrm{a}}$} \\
\hline Total burned & 7476.2 & 6.99 \\
\hline Number of patches & 18.8 & 26.96 \\
\hline$S_{\mathrm{av}}$ & 7370.4 & 7.39 \\
\hline Time to edge & 23.6 & 3.80 \\
\hline Edge/cell & 0.37 & \\
\hline \multicolumn{3}{|l|}{$W S=1, I=0.5^{\mathrm{a}}$} \\
\hline Total burned & 8324.4 & 3.52 \\
\hline Number of patches & 20.8 & 11.47 \\
\hline$S_{\mathrm{av}}$ & 8240.2 & 3.39 \\
\hline Time to edge & 23.2 & 2.20 \\
\hline Edge/cell & 0.28 & \\
\hline \multicolumn{3}{|l|}{$W S=2, I=0.3^{\mathrm{a}}$} \\
\hline Total burned & 5147.2 & 11.56 \\
\hline Number of patches & 24.6 & 17.39 \\
\hline$S_{\mathrm{ay}}$ & 5048.2 & 15.91 \\
\hline Time to edge & 18.0 & 8.90 \\
\hline Edge/cell & 0.54 & \\
\hline \multicolumn{3}{|l|}{$W S=2, I=0.4^{\mathrm{a}}$} \\
\hline Total burned & 5601.8 & 18.19 \\
\hline Number of patches & 21.2 & 32.74 \\
\hline$S_{\mathrm{av}}$ & 5498.4 & 17.49 \\
\hline Time to edge & 17.2 & 9.30 \\
\hline Edge/cell & 0.43 & \\
\hline \multicolumn{3}{|l|}{$W S=2, I=0.5^{\mathrm{a}}$} \\
\hline Total burned & 6419.6 & 16.22 \\
\hline Number of patches & 25.8 & 26.20 \\
\hline$S_{\mathrm{av}}$ & 6281.7 & 16.52 \\
\hline Time to edge & 17.6 & 10.20 \\
\hline Edge/cell & 0.36 & \\
\hline
\end{tabular}

area burned was less variable in the presence of wind because of the directional constraint of fires under high wind.

The addition of firebrands to the simulation of fire spread in homogeneous fuels caused a much more rapid advance of the fire (Fig. 3b, Table 4). Comparison of the axes of Fig. 3a and Fig. 3b indicate that firebrands caused an order of magnitude increase in the rate of spread of fires burning at $i_{c}$. Mean time-to-edge for a fire burning at $I=0.30$ was nearly four times shorter on an identically-sized landscape when spread by firebrands, and was nearly eight times shorter in the presence of WS 1 wind (Table 4). Additional increase in wind to WS 2 further decreased time-to-edge, but at a diminishing rate. Although the magnitude of the effect of firebrands is dependent on the assumptions used to derive model parameters, the high sensitivity of results to firebrand effects in homogeneous fuels, combined with the ability of firebrands to spread fires across regions of heterogeneous fuels, makes it unlikely that this sensitivity will change with more precise estimates of model parameters.

The interaction of $I$ with wind speed in the presence of firebrands resulted in categorically different behavior above and below $i_{c}$. Below $i_{c}$, increasing wind speed enhanced fire spread, so that area burned increased with wind speed (Fig. $3 b)$. However, above $i_{c}$, the no-wind condition burned the greatest area, followed by WS 2 and then WS 1. In the absence of wind, firebrands are distributed in all directions over a wide area, greatly augmenting diffusive spread. Large $I$ values ensure that spot fires started by these fire

\footnotetext{
${ }^{\text {a }}$ Fire spread is affected by wind speed and firebrands. Simulations were stopped when the fire reached the edge of the map. Summary statistics are for five replications. Units are in $50 \times 50 \mathrm{~m}$ cell $(0.25 \mathrm{ha}) . I=$ unbiased probability of fire spread from an ignited cell to one of eight unburned neighbors, where $0 \leq I \leq 1$.

${ }^{\mathrm{b}}$ The variables are: Total burned - the total number of cells burned per simulation, No. patches - the number of burned patches produced, $S_{\text {av }}$ - the area-weighted average patch size $\left[S_{\mathrm{av}}=\Sigma \mathrm{s}^{2} /(n p \Sigma s)\right.$, where $s$ is the size of an individual patch and $n_{p}$ is the number of patches], Time to edge - the number of steps required for the fire to reach the edge of the map, edge/cell — the average edge per burned cell.
} 
Table 5

Critical fraction of the landscape $\left(P_{c}\right)$ that must be occupied by each fuel type for simulated fires with diffusive spread and firebrands to burn across a $300 \times 300$ cell map in $50 \%$ of 30 simulations when the bottom row is ignited

\begin{tabular}{|c|c|c|c|c|c|}
\hline \multirow[t]{2}{*}{ Fuel type } & \multirow[t]{2}{*}{$\mathrm{FMC}^{\mathrm{a}}$} & \multicolumn{2}{|c|}{ No wind } & \multicolumn{2}{|c|}{ WS 2} \\
\hline & & $I^{\mathrm{b}}$ & $P_{c}^{\mathrm{c}}$ & $I^{\mathrm{d}}$ & $P_{c}^{\mathrm{c}}$ \\
\hline \multirow[t]{3}{*}{ LP1 } & 1 & 0.200 & DNP & 0.49 & 0.76 \\
\hline & 2 & 0.080 & DNP & 0.22 & DNP \\
\hline & 3 & 0.048 & DNP & 0.14 & DNP \\
\hline \multirow[t]{3}{*}{ LP2 } & 1 & 0.300 & 0.74 & 0.66 & 0.51 \\
\hline & 2 & 0.150 & DNP & 0.39 & 0.82 \\
\hline & 3 & 0.072 & DNP & 0.20 & DNP \\
\hline \multirow[t]{3}{*}{ LP3 } & 1 & 0.400 & 0.54 & 0.78 & 0.37 \\
\hline & 2 & 0.260 & 0.78 & 0.59 & 0.53 \\
\hline & 3 & 0.108 & DNP & 0.29 & DNP \\
\hline
\end{tabular}

a The 1000-h time lag fuel moisture classes (see text for details) are: (1) very dry, $<12 \%$, (2) dry, $12-16 \%$ and (3) moist, $>16 \%$.

${ }^{\mathrm{b}} I=$ unbiased probability of fire spread from an ignited cell to one of eight unburned neighbors, where $0 \leq I \leq 1$.

${ }^{c}$ DNP (does not propagate) indicates that a solid, uniform fuel layer is not sufficient to allow fire to burn to the top edge of the landscape in $50 \%$ of the simulations.

d Value from Table 1 modified by downwind wind bias $b=3.0$ from Fig. 2 (see text for details).

brands are likely to propagate. In the presence of wind blowing in a fixed direction, the 'seeding' of the landscape with firebrands is constrained to a more limited set of downwind sites. Allowing changes in wind direction during the fire would redirect the long fire flanks, giving wind-driven fires the potential to rapidly burn larger areas. The bias values chosen for WS 2 allowed the flanks of the fire to develop more than WS 1 (Fig. 2 ), resulting in a greater area burned. Wind-driven fires at both wind speeds produced a more finelydivided and heterogeneous burn pattern than fires burned in the absence of wind. WS 1 conditions produced a more solid burn pattern, as indicated by the smallest number of edges per cell, than WS 2 (Table 4), since the flanking development of WS 2 was restricted by lower bias factors in the off-wind directions.

Unlike adjacent spread, burn patterns produced with firebrands were not restricted to a single contiguous patch, as defined by connectivity of each cell through at least one of its eight nearest neighbors. In the absence of wind, the 'mushroom' of firebrands in all directions resulted in an order of magnitude increase in numbers of discrete, disconnected burn patches over the WS 1 burn pattern (Table 4). The WS 2 pattern contained more discrete burn patches than WS 1, but still many fewer than the pattern produced by fires unaffected by wind.

Because the frequency distribution of sizes of burn patches was highly skewed, we used the area-weighted average cluster size, $S_{\mathrm{av}}$, to statistically summarize results. $S_{\mathrm{av}}=\Sigma s^{2} /\left(n_{p} \Sigma s\right)$, where s is the size of the individual patch and $n_{p}$ is the total number of patches. Comparison of $S_{\mathrm{av}}$ with the total area burned indicates that, in every case, the burn pattern consisted of a single large cluster and many associated smaller patches. These small satellite clusters were spots started by firebrands. The low variance associated with the number of firebrand patches (Table 4) indicates that firebrand spots usually coalesced with the advancing fire front. Changes in variance showed a consistent trend in Fig. $3 \mathrm{~b}$ and Table 4. Below $i_{c}$, the variance was low because fires are quickly extinguished and few sites burned. Near $i_{c}$, the variance was high, since slight differences between simulations produced different results. Above $i_{c}$, variance was low because, once ignited, fire nearly always propagated across the landscape.

To more fully explore the effects of firebrands on the propagation of fire spread, we generated $300 \times 300$ cell maps (22 500 ha) that were randomly populated with a single fuel type at a probability $P$, and ignited the bottom row of each simulated landscape. Thirty simulations were performed for each value of $P$, and the number of simulations in which the fire reached the top edge of the map was recorded. Iterative adjustment of the value of $P$ allowed us to converge on the critical fraction, $P_{c}$, occupied by a particular fuel type that permits $50 \%$ of the simulations to cross the landscape.

Under the no wind condition and all fuel moisture classes, fewer than $50 \%$ of the fires crossed the landscape in LP1 fuels when $P=1.0$, indicating that fires spread with firebrands are unlikely to propagate under these conditions (Table 5). Because the value of $I$ for NF and LP0 fuel types 
is equal to or less than LP1 (Table 1), fires in NF and LP0 fuels will also fail to propagate across the landscape. When wind speeds were high (WS 2) from the south, fires in LP1 fuels did propagate
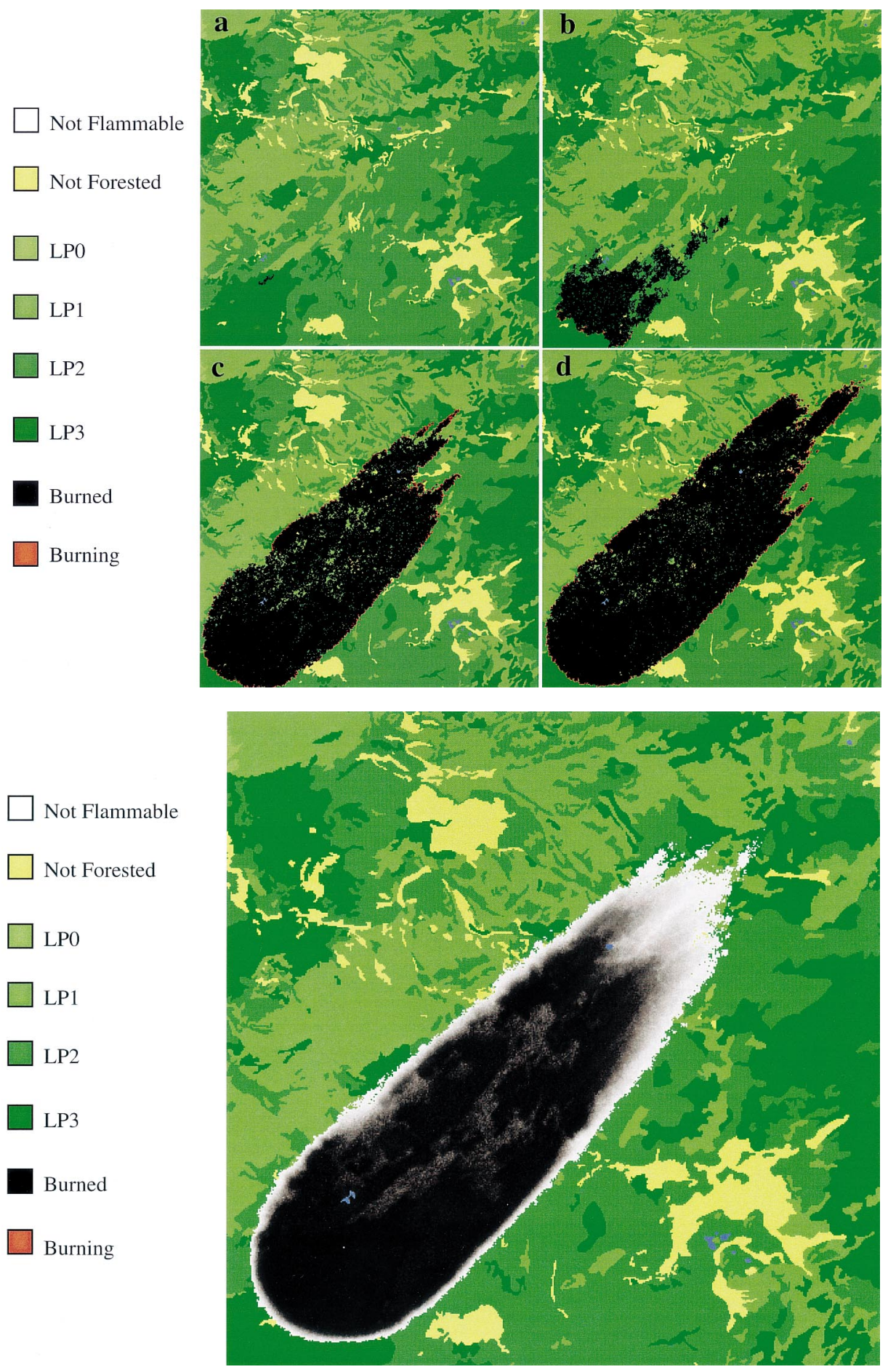

Figs. 4 and 5 . 
under very dry fuel moisture conditions when the critical fraction, $P_{c}$, was at least 0.76 (Table 5). LP2 fuels allowed fires to propagate across the landscape only when it was very dry without wind, but fires propagated across both dry and very dry LP2 fuels when driven by high winds. The most combustible LP3 fuels propagated fires over the broadest range of conditions. However, even LP3 fuels did not propagate fires when fuel moisture was high (Table 5). Wind-driven fires were able to propagate across low-occupancy landscapes $\left(P_{c}=0.37\right.$ for LP3 fuels, high winds and very dry conditions, Table 5), while the no wind conditions required an approximately $15-25 \%$ greater fraction of the landscape to be occupied by combustible fuels.

\subsection{Simulations using actual landscape patterns}

The effect of the spatial configuration of fuel classes on the spread of fire was simulated on a $500 \times 500$ cell map depicting a $25 \times 25 \mathrm{~km}$ section (62 500 ha) of the subalpine plateau in YNP east of West Yellowstone, Montana, and north of the Old Faithful geyser basin (UTM coordinates of SW corner $=4927225 \mathrm{~m} \mathrm{~N}, 494025 \mathrm{~m} \mathrm{E}$ ). Data describing the spatial distribution of fuel classes prior to the extensive fires of 1988 were obtained from the Park's Geographic Information System laboratory from data compiled by Despain (1990) from 1:15840 scale color aerial photographs taken from 1969 to 1971 . The 40 vegetation types described by Despain (1990) were combined and reclassified into the six fuel classes described above. All the simulations were run on the same landscape using a single ignition point in the LP3 fuel type near the southwest corner of the map. To simplify the simulation experiment, wind was present in each simulation (WS 1 or 2) and wind direction was set from the southwest, the prevalent wind direction in YNP during the summer (Dirks 1976). Simulated fires were replicated five times, and were permitted to burn until they reached the edge of the map or until all the fires went out.

Four scenarios, representing conditions which may occur during fire seasons at YNP, were simulated. Scenario 1 represented moist conditions ( $>16 \%$ 1000-h fuel moisture) and high winds (WS $2,>21.7 \mathrm{kph}$ ) from the southwest. Such conditions are common in YNP in early summer (June), and may continue throughout the summer in wet years. Scenario 2 represented moderately dry moisture conditions (12-16\%), and moderate winds (WS 1, $3.1-21.7 \mathrm{kph})$. Scenario 3 represented very dry weather ( $<12 \% 1000$-h fuel moisture), and moderate winds (WS 1, 3.1-21.7 kph). Such conditions are experienced in late summer during 2-3 years per decade, e.g. 1976, 1979, and 1981 (Despain, 1990; Renkin and Despain, 1991). Scenario 4 represented extreme fire conditions with very dry weather $(<12 \%)$, and strong winds (WS 2, > 21.7 $\mathrm{kph}$ ). These conditions approximate those during the extensive 1988 fires in YNP, and may occur only every century or so (Romme and Despain, 1989).

Actual fires under moist conditions in YNP rarely burn much area, even when driven by high winds (Despain, 1990; Renkin and Despain, 1991), and the simulated fires also demonstrated this behavior (Fig. 4a). Under damp fuel conditions, even high winds failed to produce $I$ values close to or above $i_{c}$. Therefore, the burn was limited almost entirely to the LP3 fuel type where it began, and only a few firebrand spots occurred in the down-

Fig. 4. Typical final fire patterns produced under alternative weather conditions of (a) Scenario 1: 'moist' weather conditions ( $>16 \%$ 1000-h time lag fuel moisture), 'strong' winds (wind speed class 2, >21.7 kph) from the southwest, with adjacent spread and firebrands; (b) Scenario 2: 'dry' weather conditions (12-16\% 1000-h time lag fuel moisture), 'moderate' winds (wind speed class 1, $3.1-21.7 \mathrm{kph}$ ) from the southwest, with adjacent spread and firebrands; (c) Scenario 3: 'very dry' weather conditions ( $<12 \% 1000$-h time lag fuel moisture), 'moderate' winds (wind speed class $1,3.1-21.7 \mathrm{kph}$ ) from the southwest, with adjacent spread and firebrands; and (d) Scenario 4: 'very dry' weather conditions ( $<12 \% 1000$-h time lag fuel moisture), 'strong' winds (wind speed class $2,>21.7 \mathrm{kph}$ ) from the southwest, with adjacent spread and firebrands. Region is a $500 \times 500$ cell landscape from the Yellowstone central plateau just east of West Yellowstone, Montana, and just north of the upper geyser basin and Old Faithful area. There is a single fixed ignition in LP3 fuel near the southwest corner of the map. Black color indicates extent of burned area. Blue indicates water. Simulation was stopped when the fire went out or reached the edge of the map.

Fig. 5. Risk map produced by summing results of 50 independent simulations of a fire burning under conditions of Scenario 3 , 'very dry' weather with 'moderate' winds. Levels of gray indicate the proportion of simulations in which each cell burned, where black cells burned in all simulations and white cells burned in only a single replicate (see text for additional details). 
Table 6

Fire pattern statistics in a $500 \times 500$ cell heterogeneous landscape from the Yellowstone central plateau burned under four synoptic fuel/weather scenarios with a single fixed ignition ${ }^{\mathrm{a}}$

\begin{tabular}{|c|c|c|}
\hline Variable $^{\mathrm{b}}$ & Mean & $\mathrm{CV}$ \\
\hline \multicolumn{3}{|l|}{ Scenario $1^{\mathrm{c}}$} \\
\hline Total burned & 19.2 & 96.5 \\
\hline No. patches & 1.6 & 34.2 \\
\hline$S_{\mathrm{av}}$ & 11.0 & 85.7 \\
\hline Edge/cell & 3.90 & \\
\hline \multicolumn{3}{|l|}{ Scenario $2^{\mathrm{d}}$} \\
\hline Total burned & 12793.6 & 22.7 \\
\hline No. patches & 24.4 & 35.6 \\
\hline$S_{\mathrm{av}}$ & 11791.6 & 27.6 \\
\hline Edge/cell & 1.10 & \\
\hline \multicolumn{3}{|l|}{ Scenario $3^{\mathrm{e}}$} \\
\hline Total burned & 58183.2 & 4.3 \\
\hline No. patches & 30.8 & 12.6 \\
\hline$S_{\mathrm{av}}$ & 57643.6 & 4.7 \\
\hline Edge/cell & 0.47 & \\
\hline \multicolumn{3}{|l|}{ Scenario $4^{\mathrm{f}}$} \\
\hline Total burned & 77441.2 & 3.6 \\
\hline No. patches & 39.8 & 16.9 \\
\hline$S_{\mathrm{av}}$ & 77047.6 & 3.7 \\
\hline Edge/cell & 0.33 & \\
\hline
\end{tabular}

\footnotetext{
${ }^{\text {a }}$ Wind is from the southwest, and propagation is by diffusive spread and firebrands. Simulation was stopped when fire went out or reached the edge of the grid. Summary statistics are for five replications. Units are in $50 \times 50 \mathrm{~m}$ cells $(0.25 \mathrm{ha})$.

b The variables are: total burned-the total number of cells burned per simulation, number of patches-the number of fire patches produced, $S_{\mathrm{av}}$ is the area-weighted average patch size $\left[S_{\mathrm{av}}=\Sigma s^{2} /\left(n_{p} \Sigma s\right)\right.$, where $s$ is the size of an individual patch and $n_{p}$ is the number of patches]; edge/cell - the average edge per burned cell.

${ }^{\mathrm{c}}$ Scenario 1: moist with strong winds, fuel moisture class 3 $(>16 \%, 1000-\mathrm{h}$ time lag fuel moisture), wind speed class 2 [>21.7 kph $(>35 \mathrm{mph})]$.

d Scenario 2: dry with moderate winds, fuel moisture class 2 (12-16\% 1000-h time lag fuel moisture), wind speed class 1 [3.1-21.7 kph (5-35 mph)].

e Scenario 3: very dry with moderate winds, fuel moisture class $1(12-16 \%, 1000-\mathrm{h}$ time lag fuel moisture), wind speed class 1 [3.1-2.7 $\mathrm{kph}(5-35 \mathrm{mph})]$.

${ }^{\mathrm{f}}$ Scenario 4 : very dry with strong winds, fuel moisture class $1(<12 \%, 1000$-h time lag fuel moisture), wind speed class 2 [>21.7 kph $(>35 \mathrm{mph})]$.
}

wind LP1 fuels. This moist fire scenario produced a small, dendritic burn with a relatively large amount of edge per cell, even though directed by strong wind (Table 6). Moist conditions produced small burns of variable size, with a large coefficient of variation; one of five replications burned only the initially-ignited cell. The final burn consisted of essentially a single cluster (mean number of patches $=1.6$, Table 6).

The result of one simulation for Scenario 2, representing moderately dry conditions, is shown in Fig. 4b. Fires under these conditions were much larger, burning out the LP3 patch where they started, and skipping over the adjacent LP2 to connect with islands of LP3 fuels downwind. Scenario 2 produced a final burn pattern with less edge per cell than Scenario 1 (Table 6). The burned area showed embedded unburned cells even in LP3, and the fire pattern was even more heterogeneous in LP2. Only light spotting occurred in LP1 fuels. Burning conditions in YNP during the 1979 fire season were similar to those simulated under this scenario (Renkin and Despain, 1991).

The drier weather of Scenario 3 resulted in a much larger area burned (Fig. 4c, Table 6). Burned areas in LP3 were nearly solid black (Fig. $4 c)$, and nearly all of LP2 was burned as well. The fire made good progress into LP1 fuels downwind, and the final burn pattern is approaching a downwind ellipse, as other simulations have predicted (Andersen, 1983; Green, 1983; Green et al., 1983). The final burn had less edge per cell and was disconnected into a few more clusters. The actual Forest Lake, Witch, and Two Ocean fires in YNP in 1981 burned under similar conditions (Renkin and Despain, 1991).

Extreme fire conditions (Scenario 4) produced a pattern similar to that of Scenario 3. However, higher wind speed resulted in larger burned areas (Table 5), and the fire had a more elliptical fire shape (Fig. 4d) because of higher lateral bias values in WS 2 winds. There was only a slight decrease in number of burned edges per cell although the final burn consisted of more separate fire patches due to the greater average dispersal distance for firebrands.

The stochastic variability in results of repeated simulations can be summarized as $F_{i}=n_{i} / N$, where $n_{i}$ is the number of times that site $i$ was burned in all replications, $N$ is the total number of simulations and $F_{i}$ is the frequency or likelihood 
of fire at cell $i$. A map showing $F_{i}$ as shades of gray, where each cell is white as $F_{i}$ approaches 0 and black as $F_{i}$ approaches 1 , indicates the spatial relationship of risk of burning in this landscape given this ignition and burning under the conditions of Scenario 3 (Fig. 5). Outlines of the lessflammable fuel types can be seen within the burned perimeter as lighter areas at lower risk of burning.

The cumulative frequency distribution of fire for 50 simulations of each scenario plotted against the area burned (Fig. 6) estimates the risk of fires of particular sizes under each scenario. If the left side of the risk curve intercepts the $y$-axis, the intercept represents the proportion of replicate simulations which never burned more than the initially-ignited cell. If the risk curve intercepts the $x$-axis, the intercept represents the number of cells that burned in every replicate simulation - a minimum expected fire size. The area burned at a cumulative risk of 1.0 represents the largest fire among all replicates - the maximum area within the landscape that is at risk.

Cumulative risk curves for Scenario 1 and 2
(Fig. 6 a and b, respectively) intersect the ordinate, indicating that fires went out in some replicates. Fig. 6 shows that $50 \%$ of the fires in Scenario 1 failed to propagate beyond the ignition point, and that $90 \%$ of the replicates burned an area $\mathfrak{x} 41$ cells $(10.25$ ha). The risk curve for Scenario 2 shows that $4 \%$ of these fires did not spread beyond the ignition point, that $50 \%$ of the simulations burned within an area at least as large as 6955 cells (1739 ha), and that $90 \%$ of the simulated fires burned an area $\leq 12300$ cells (3075 ha). The curves for Scenario 3 and 4 are similar in shape, with the higher winds of Scenario 4 resulting in a greater area of the landscape being at risk. There is a $50 \%$ chance in Scenario 3 of burning as $\leq 45131$ cells (11 283 ha), while Scenario 4 burned $32.6 \%$ more area at this same level of risk (59 636 cells and 14909 ha). Similarly, there is a $90 \%$ chance of burning $\leq 52617$ (13 154 ha) in Scenario 3 while $\leq 68810$ cells (17 202 ha) can be expected to burn under weather and wind conditions described in Scenario 4 at the same level of risk.

Effects of uncertainties in particular model parameters on these risk curves were evaluated by

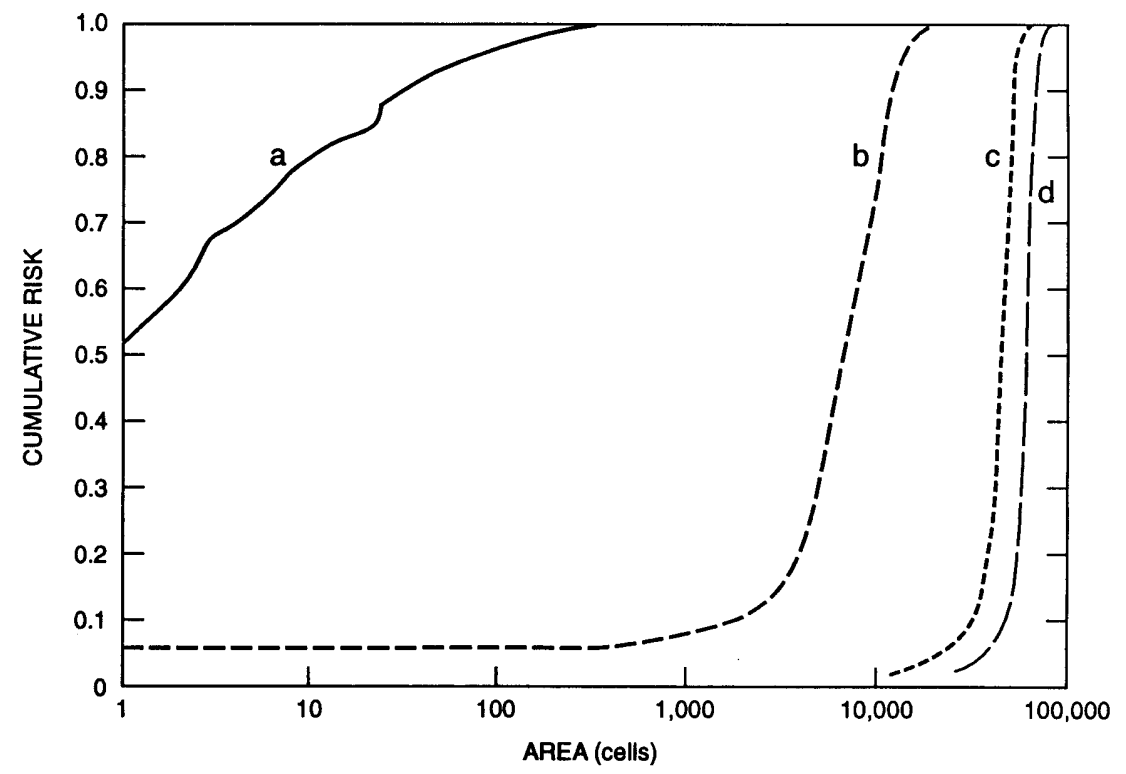

Fig. 6. The cumulative frequency of risk of fires of increasing size for four alternative weather conditions of (from left to right) (a) Scenario 1: 'moist' with 'strong' winds; (b) Scenario 2: 'dry' weather with 'moderate' winds; (c) Scenario 3: 'very dry' weather with 'moderate' winds; and (d) Scenario 4: 'very dry' weather with 'strong' winds (see text for additional details). 
a series of systematic perturbations of the $I$ matrix (Table 1), the wind bias terms, and the number of firebrands produced by each burning cell. Uncertainties were evaluated by repeated sets of 50 iterations each of Scenario 3 with (1) all values of the $I$ matrix increased or decreased by $10 \%$; (2) all wind bias terms increased or decreased by $50 \%$; and (3) the number of firebrands produced by each fuel type (Table 2) increased or decreased by $50 \%$. The parameters and ranges of values selected for these perturbations represent our estimates of likely sources of model uncertainty. The effect of $I$ on the propagation and resulting pattern of percolation phenomena like fires is well understood (Albinet et al. 1986; Stauffer and Aharony 1992), so actual values for the $I$ matrix should be within $\pm 10 \%$ of the values presented in Table 1. Estimates of the wind bias terms are less certain. Although elliptical burn patterns are produced by wind (Green et al. 1990; Richards 1993), the range of wind bias terms necessary to produce this effect could be as large as $\pm 50 \%$. The number of firebrands produced by burning cells of different fuel types is probably the least certain of all, with a range of values of at least $\pm 50 \%$.

The largest changes in the risk curves with parameter perturbation (Fig. 7) were associated

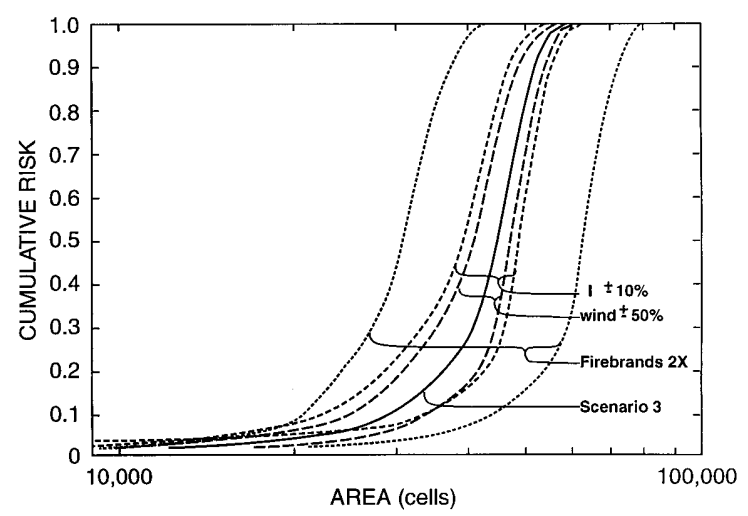

Fig. 7. Comparison of the cumulative frequency of risk of fires for weather Scenario 3 (central curve, solid line, as in Fig. 6c), doubling and halving the number of firebrands produced from each burning cell (outermost pair of curves, fine dashes), changing all values of the $I$ matrix by $\pm 10 \%$ (middle pair of curves, medium dashes), and changing the wind bias terms by $\pm 50 \%$ (innermost pair of curves, coarse dashes). See text for additional details. with changes in the number of firebrands produced by each fuel type - the number of cells burned at the 50th percentile differed by a factor of 2 (30 848-62 933 cells, or 7712-15 $733 \mathrm{ha}$ ). Variation of the $I$ matrix by $\pm 10 \%$ had a larger effect on the risk curves than varying the wind bias terms by $\pm 50 \%$ (Fig. 7). The risk curves for the $I$ matrix ranged from 39221 to 48985 (10 252-11 $817 \mathrm{ha}$ ) at the 50th percentile, while the risk curves for the $\pm 50 \%$ variation on the wind bias terms ranged from 41010 to 47268 (10 252-11 817 ha). Examination of the maximum increase in the median risk levels from the Scenario 3 base case shows that uncertainties in the number of firebrands increased the 50th percentile by $39.5 \%$, while increases in $I$ and wind bias terms resulted in an 8.5 and $4.7 \%$ increase, respectively. The difference between the 50th percentile of Scenario 3 and 4 is $32.1 \%$. Only the perturbation of the firebrand parameters produced a greater change in risk than differences in weather conditions between Scenario 3 and 4 (Fig. 6 ). Therefore, the availability of precise fuel moisture and wind speed measurements is relatively more important for risk management than increased precision in the estimates of $I$ and wind bias terms. However, imprecision in the estimates of the number of firebrands produced by each fuel type can produce changes in fire patterns as great as that due to changes in weather conditions.

\section{Discussion}

The results of EMBYR simulations for the four weather scenarios illustrate the potential interactions between thresholds in landscape pattern (i.e. the continuity of combustible fuels across the landscape) and weather conditions on the likelihood of large fires (Turner and Romme, 1994). Under moist conditions (1000-h time lag fuel moisture $>16 \%$, Scenario 1), weather prevented fire from spreading and large fires did not occur (Fig. 5). However, under very dry and windy conditions (1000-h time lag fuel moisture $<12 \%$, Scenario 3 and 4) large fires occurred and quickly spread across the landscape. Since firebrands were distributed downwind, the landscape pattern of 
combustible fuels was less important for describing the spatial extent of fires in Scenario 3 and 4. Table 5 shows that, under conditions similar to the weather conditions during the 1988 fires, the least combustible forest fuels (LP1) still propagated fire if at least $76 \%$ of the landscape was occupied by this fuel type. This result is consistent with the observation that, during the YNP fires of 1988, crown fires easily spread through all fuel types (Rothermel 1991). Bessie and Johnson (1995) found that historical fire initiation and intensity in subalpine conifer stands are correlated more strongly with the weather components than the fuel components of both (Rothermel, 1972, 1983) surface fire model and Van Wagner (1977) crown fire model. Since most of the YNP subalpine plateau is covered with continuous lodgepole pine stands, the critical fraction $\left(P_{c}\right)$ is usually exceeded when fuels are very dry. However, under moderately dry conditions with less severe winds (1000-h time lag fuel moisture between 12 and $16 \%$, wind speeds $3.1-21.7 \mathrm{kph}$, Scenario 2), the simulated fires were constrained by the spatial arrangement of the most flammable fuel types (Fig. 4b). Under these conditions, the interaction of landscape pattern and fire dynamics was a more important determinant of fire pattern.

Changes in the magnitude of the probability of spread, $I$, relative to the critical threshold $i_{c} \approx 0.25$ had a dramatic effect on the pattern of burn. Fire spread in EMBYR is simulated as a bond percolation process (Stauffer and Aharony, 1992); therefore, we expect critical thresholds to exist. Models of forest fire based on percolation theory have been extensively used for over 10 years (e.g. MacKay and Jan, 1984; Albinet et al., 1986; Ohtsuki and Keyes, 1986). The Monte Carlo simulations showed that burn patterns are most variable when $I$ is near the critical threshold, $i_{c}$. Simulated fires were small when $I<i_{c}$, and area burned increased with $I>i_{c}$. However, both the area burned and shape of the burn, as indicated by the amount of edge per cell, showed their greatest variance when $I$ is between 0.20 and 0.30 . Given dry enough conditions for burning, fuel moisture had a greater effect on simulated fire patterns than increases in wind speed (e.g. compare the difference in area burned between Scenario 2 and 3, a fuel moisture class difference, with that between Scenario 3 and 4, a wind speed class difference, Table 6 and Fig. 5). That is, the inherent tendency of the fuel class to propagate the fire was more important than the enhanced directional spread resulting from wind. Actual fires in YNP during 1972-1988 burning at or near $13 \% 1000$-h time lag fuel moisture were constrained primarily by fuel type, and strong winds were able to buffer or supersede this combined influence only for 'short durations' (Renkin and Despain, 1991). This suggests that the parameterization of $I$ values for appropriate fuel moisture classes is crucial to landscape-scale fire simulation.

Simulated fire dynamics were dramatically affected by the inclusion of firebrands in the simulations. Firebrands enhance the ability of the fire to cross potential barriers and less combustible regions where the probability of diffusive spread is less than the critical threshold. Including firebrands in the simulations increased both the rate of fire spread and the total area burned substantially more than increases in the probability of spread to adjacent neighbors. The importance of firebrands in our simulations is consistent with the concern of fire fighters with spotting behavior, particularly during favorable burning conditions. However, there are differences between spotting observed in real fires and firebrands simulated in the model. Fire fighters usually consider spotting behavior to be the establishment of separate burning patches sufficiently far beyond the advancing fire front that they are perceived as distinct spot fires. As used in our model, firebrands often fall near the cell that generated them. Thus, simulated ignitions from firebrands increase the speed of the advancing front, without necessarily creating distinct fires in the conventional sense. In actual fires, firebrands falling just ahead of the advancing front of the fire may be as important as diffusive spread in moving the fire across the landscape.

The variability among simulations using the same set of parameters (Fig. 3), the difficulty of predicting fire behavior when $I$ is close to $i_{c}$, and 
the uncertainties associated with future weather conditions were summarized as the cumulative risk of burning areas of increasing size (Fig. 6). The differences in results between scenarios (Fig. 6) illustrate the effects of critical thresholds on fire size. Table 3 shows that values of $I$ in Scenario 1 (high moisture, moderate winds) were below the threshold value needed to produce a significant fire even if $100 \%$ of the landscape were composed of LP3, the most combustible fuel type. However, the drier conditions of Scenario 2 resulted in values of $I$ that will cause $50 \%$ of the fires to burn an area at least as large as 1739 ha. As conditions became drier and windier, the cumulative risk of large fires also increased (Fig. 6).

The cumulative risk curves (Fig. 6) are always monotonically increasing; if the curve sweeps upward in a concave shape, the risk map (Fig. 5) is comprised mostly of dark areas of high $F_{i}$, indicating that most iterations produced similar patterns of fire. Convex risk curves result from risk maps containing many cells of low $F_{i}$, indicating that some iterations burned an area larger than the average. Thus, the form of the cumulative risk function reflects the predictability of the simulated fire. This predictability is independent of the final size of the burn, representing instead the variability in the final burn pattern. The risk curves in Fig. 6, for example, represent a spectrum of predictability which is the inverse of their average sizes (Table 6).

The risk curves also provided a parsimonious means of evaluating the relative importance of variation in model parameters on predicted results (Bartell et al. 1992). The perturbation of model parameters over likely ranges of variation indicates that uncertainties in firebrand numbers caused a much greater change in results than perturbations of the probabilities of spread, $I$, or wind bias terms. Comparisons of the curves in Fig. 7 with those for the different weather scenarios in Fig. 6 showed that, except for firebrands, the uncertainties associated with $I$ and with the wind bias terms were less than differences between weather conditions.

The importance of weather is well understood (Clark, 1988; Johnson et al., 1990; Swetnam and Betancourt, 1990; Rothermel, 1991; Johnson,
1992; Davis and Burrows, 1994; Bessie and Johnson, 1995), but accurate estimates of firebrand effects are lacking. The difficulty is that fire spots result from a complex interplay of the number of firebrands produced, firebrand dispersal distances, ignition probabilities of the recipient fuel class, and the spatial arrangement of fuel types. Simply observing large fires, or performing a post-fire analysis of the pattern of burn, will not provide an adequate characterization of the effect of firebrands on the process of fire spread. The number of firebrands produced by each fuel type and the probability of ignition may have compensating effects on spotting behavior; greater numbers of less-successful firebrands may produce the same pattern as fewer, more-successful ones. Similarly, the $I$ values for each fuel type, in concert with the mean dispersal distance for firebrands, determine the rate of spread for fire. Several combinations of these parameters probably produce similar burn patterns.

The validation of model results, in the strictest sense, remains unresolved. Even in YNP, where there has been a significant and longstanding interest in fire, historical fire weather data have poor resolution, both spatially $(<10$ weather stations) and temporally (i.e. 1 point observation of windspeed/direction each $24 \mathrm{~h}$ ). Although we believe that parameters for EMBYR could be developed so that the simulations would match any single historical fire, the poor resolution of the historical weather data, coupled with uncertainty in the model parameters (particularly firebrands) would make this an unprofitable exercise. Rather, our probability-based approach has been to consider that each particular fire has a range of possible behavioral outcomes, and that small, chaotic events result in a single realization within that range of possible behaviors. One could easily imagine (as fire fighters do) that small changes in conditions could significantly alter the series of events that were realized. Therefore, we believe that the best model validation for EMBYR is to produce probabilistic results which characterize the range and expected patterns of single or multiple fire events.

Knowledge of the critical threshold, $i_{c}$, for diffusive spread and the critical fraction, $P_{c}$, of the 
landscape, that is susceptible to fire (Table 5) is useful for evaluating potentially serious fire events. When fuel type and weather conditions (fuel moisture and wind) result in values of $I$ being less than $i_{c}$, we can expect fires to die quickly and spread to be confined to a small area (e.g. Scenario 1, Table 6). This has not gone unnoticed by practitioners of controlled fire; prescriptions of conditions acceptable for controlled burning used by federal agencies are designed to keep managed fires from escaping control, i.e. going critical. Above the critical threshold, $i_{c}$, the proportion of the landscape occupied by the most combustible fuel type and its spatial configuration will dominate fire dynamics (Table 5). Fuel density, $P$, can be estimated for areas of responsibility from remote imagery. Knowledge of these relationships then allows managers to evaluate the effect of landscape heterogeneity of fuels on the risk of large fires under variable weather conditions.

The simulations reported here assumed constant conditions of fuel moisture, wind speed, and wind direction while fires were burning. However, EMBYR can also use actual weather and fuel moisture conditions that change over a fire season, or even a single fire event, to simulate the temporal dynamics that contribute to observed fire patterns (Gardner et al. 1996). Fire intensity and burn severity are not absolute but variable, and this variable pattern affects subsequent vegetation recovery and re-establishment (Moreno and Oechel, 1994; Huff, 1995; Turner et al., 1997). EMBYR also considers variable rates of combustion and the resulting effect of variability of fire severity on the recovery of vegetation. Also included in EMBYR, but not discussed here, is the consideration of topographic effects on fire behavior (see http://www.esd.ornl.gov/ern/embyr/embyr.html for an example simulation that includes these factors).

The importance of wind in producing the final pattern of fire effects, and the uncertainty associated with projecting wind directions from one or two weather stations would make it desirable to include spatially dynamic wind fields (e.g. Zack and Minnich, 1991) in future model simulations. Doppler next-generation radars (NEXRAD) could potentially supply wind field data, as well as spatially explicit precipitation maps, which could be used to adjust fuel moisture levels during fire events. This has not yet been accomplished.

EMBYR was developed because no single model considers the necessary combination of factors for simulating fire effects in heterogeneous landscapes. Since the return interval of large fires is long (Romme, 1982; Romme and Despain, 1989), and the pattern of spread that each fire produces is highly variable (Johnson, 1992), it is difficult to rely solely on historical and empirical methods to evaluate the effect of landscape heterogeneity and weather conditions on the frequency, extent and pattern of fires.

We believe that EMBYR is a useful synthetic tool for understanding ecological effects of fire dynamics in heterogeneous landscapes. The spatially explicit simulation of fire effects can be used to evaluate the risk (Figs. 5 and 6) associated with large fires as a function of changing weather conditions and the spatial heterogeneity of fuels. The variance inflation that occurs near the critical conditions suggests important changes in perspectives used by managers who adopt the risk approach. Although EMBYR is designed with Yellowstone fuel types in mind, the generality of the model allows it to be used in other landscapes by estimating parameters for different fuel types. While verification of simulations of rare events will always be problematic, a model that includes these realistic features would be a useful tool for analysis of the variability of weather conditions on the risk of large fires, the uncertainties associated with prescribed burns, and the exploration of frequency of large fires under scenarios of future climatic change.

\section{Acknowledgements}

Special thanks are due to G. McKay of the YNP GIS Laboratory for access to GIS base maps and to R. Rothermel, J. Brown, P. Anderson, and B. Hartford of the USDA Forest Service, Intermountain Fire Sciences Laboratory, Missoula, MT, for providing a broad range of advice and information regarding fire behavior. 
We greatly appreciate the interest and assistance of R. Renkin and P. Perkins in collecting and evaluating valuable information on the history of YNP fires. The comments and suggestions of R. Plotnick and R. Flamm are appreciated. Plotnick's insight regarding the behavior of simulations on square lattices was particularly valuable. Research funded by grants from the National Science Foundation (BSR-9016281 and BSR9018381) and the Ecological Research Division, Office of Health and Environmental Research, U.S. Department of Energy under contract no. DE-AC05-84OR24400 with Lockheed Martin Energy Systems, Inc. Environmental Sciences Division Publication No. 4444, ORNL.

\section{References}

Albinet, G., Searby, G., Stauffer, D., 1986. Fire propagation in a 2-D random medium. J. Phys. 47, 1-7.

Albini, F.A., 1976. Estimating wildfire behavior and effects. USDA Forest Service General Technical Report INT-30.

Albini, F.A., Stocks, B.J., 1986. Predicted and observed rates of spread of crown fires in immature jack pine. Combust. Sci. Technol. 48, 65-76.

Andersen, H.E., 1983. Predicting wind-driven wild land fire size and shape. USDA Forest Service General Technical Report, INT-305.

Andrews, P.L., Chase, C.H., 1989. BEHAVE: Fire Behavior Prediction and Fuel Modeling System - BURN Subsystem Part 2. National Wildfire Coordinating Group Publication PMS 439-3, NFES 277.

Antonovski, A.Y., Ter-Mikaelian, M.T., Furyaev, V.V., 1992. A spatial model of long-term forest fire dynamics and its applications to forests in western Siberia. In: Shugart, H.H., Leemans, R., Bonan, G.B. (Eds.), A Systems Analysis of the Global Boreal Forest. Cambridge University Press, Cambridge, pp. 373-403.

Baker, W.L., 1993. Spatially heterogeneous multi-scale response of landscapes to fire suppression. Oikos 66, 66-71.

Baker, W.L., Egbert, S.L., Frazier, G.F., 1991. A spatial model for studying the effects of climatic change on the structure of landscapes subject to large disturbances. Ecol. Model. 56, 109-125.

Bartell, S.M., Gardner, R.H., O’Neill, R.V., 1992. Ecological Risk Estimation. Lewis Publishers, Chelsea, MI, p. 252.

Bessie, W.C., Johnson, E.A., 1995. The relative importance of fuels and weather on fire behavior in subalpine forests. Ecology 76, 747-762.

Burgan, R.E., Rothermel, R.C., 1984. BEHAVE: Fire behavior prediction and fuel modeling system. USDA Forest Service General Technical Report INT-167.
Clark, J.S., 1988. Effect of climate change in fire regimes in northwestern Minnesota. Nature 334, 233-235.

Clarke, K.C., Brass, J.A., Riggan, P.A., 1994. A cellular automation model of wildfire propagation and extinction. Photogrammetric Eng. Remote Sensing 60 (11), 13551367.

Clarke, K.C., Olsen, G., Brass, J.A., 1993. Refining a cellular automaton model of wildfire propagation and extinction. In: Proceedings, Second International Conference on the Integration of Geographic Information Systems and Environmental Modelling, Breckenridge, CO, USA.

Davis, F.W., Burrows, D.A., 1994. Spatial simulation of fire regimes in Mediterranean-climate landscapes. In: Moreno, J.M., Oechel, W.C. (Eds.), The Role of Fire in Mediterranean-type Ecosystems. Springer, Berlin, pp. 117-139.

Dirks, R.A., 1976. Climatological studies of Yellowstone and Grand Teton National Parks: Continuing Studies Annual Report. Department of Atmospheric Science, College of Engineering, University of Wyoming, Laramie, WY.

Despain, D.G., 1977. Forest successional stages in Yellowstone National Park. Inf. Pap. No. 32.

Despain, D.G., 1990. Yellowstone Vegetation: Consequences of Environment and History in a Natural Setting. Roberts Rinehart, p. 239.

Finney, M.A., 1993. Modeling the spread and behavior of prescribed natural fires. Proceedings of the 12th International Conference on Fire and Forest Meteorology, 26-28 October, 1993, Jekyll Island, GA, pp. 138-143.

Finney, M.A., 1999. Mechanistic modeling of landscape fire patterns. In: Mladenoff, D.J., Baker, W.L. (Eds.), Spatial Modeling of Forest Landscapes: Approaches and Applications. Cambridge University Press, Cambridge, pp. 186209.

Fosberg, M.A., Deeming, J.E., 1971, Deviation of the 1- and 10-h timelag fuel moisture calculations for fire-danger rating. Res. Note RM-207. USDA Forest Service Intermountain Forest and Range Experiment Station, p. 8.

Gardner, R.H., O’Neill, R.V., 1991. Pattern, process and predictability: the use of neutral models for landscape analysis. In: Turner, M.G., Gardner, R.H. (Eds.), Quantitative Methods in Landscape Ecology. Springer, Berlin, pp. 289-308.

Gardner, R.H., Hargrove, W.W., Turner, M.G., Romme, W.H., 1996. Climate change, disturbances and landscape dynamics. In: Walker, B., Steffen, W. (Eds.), Global Change and Terrestrial Ecosystems, IGBP Book Series No. 2. Cambridge University Press, Cambridge, pp. 149-172.

Gardner, R.H., Romme, W.H., Turner, M.G., 1999. Predicting forest fire effects at landscape scales. In: Mladenoff, D.J., Baker, W.L. (Eds.), Spatial Modeling of Forest Landscapes: Approaches and Applications. Cambridge University Press, Cambridge, pp. 163-185.

Grassberger, P., 1985. On the spreading of two-dimensional percolation. J. Phy. A: Mathemat. Gen. 18, 215-219.

Green, D.G., 1983. Shapes of simulated fires in discrete fuels. Ecol. Model. 20, 21-32. 
Green, D.G., 1989. Simulated effects of fire, dispersal, and spatial pattern on competition within forest mosaics. Vegetatio 82, 139-153.

Green, D.G., Tridgell, A., Gill, A.M., 1990. Interactive simulation of bushfires in heterogeneous fuels. Mathemat. Comput. Model. 13, 57-66.

Green, D.G., Gill, A.M., Noble, I.R., 1983. Fire shapes and the adequacy of fire-spread models. Ecol. Model. 20, 33-45.

Hirabayashi, F., Kasahara, Y., 1987. A fire-spread simulation model developed as an extension of a dynamic percolation process model. Simulation 49, 254-261.

Huff, M.H., 1995. Forest age structure and development following wildfires in the western Olympic mountains, Washington. Ecol. Appl. 5, 471-483.

Izbecki, S., Keane, R., 1989. An attempt at developing a crown fire ignition model. Final Report INT-88352-COA. US Forest Service, Intermountain Fire Sciences Laboratory, Missoula, Montana.

Johnson, E.A., 1992. Fire and Vegetation Dynamics. Cambridge University Press, Cambridge, UK.

Johnson, E.A., Fryer, G.I., Heathcott, M.J., 1990. The influence of man and climate on frequency of fire in the interior wet belt forest, British Columbia. J. Ecol. 78, 403-412.

Keane, R.E., Ryan, K.C., Running, S.W., 1996a. Simulating effects of fire on northern Rocky Mountain landscapes with the ecological process model FIRE-BGC. Tree Physiol. 16, 319-331.

Keane, R.E., Morgan, P., Running, S.W., 1996. FIRE-BGC-A mechanistic ecological process model for simulating fire succession on coniferous forest landscapes of the Northern Rocky Mountains. USDA Forest Service Intermountain Research Station Research Paper: RP-484.

Kessell, S.R., 1976. Gradient Modeling: a new approach to fire modeling and wilderness resource management. Environ. Manage. 1, 39-48.

Kessell, S.R., 1979. Gradient Modeling: Resource and Fire Management. Springer, New York, p. 432.

Kourtz, P., O'Regan, W.G., 1971. A model for a small forest fire. For. Sci. 17, 163-169.

MacKay, G., Jan, N., 1984. Forest fires as critical phenomena. J. Phys. A: Mathemat. Gen. 17, L757-L776.

Meakin, P., 1986. Universality, nonuniversality, and the effects of anisotropy on diffusion-limited aggregation. Phys. Rev. A33, 3371-3382.

Moreno, J.M., Oechel, W.C., 1994. Fire intensity as a determinant factor of postfire recovery in Southern California chaparral. In: Moreno, J.M., Oechel, W.C. (Eds.), The Role of Fire in Mediterranean-type Ecosystems. Springer, Berlin, pp. $26-45$.

Nahmias, J., Tephany, H., Guyon, E., 1989. Propagation de la combustion sur un reseau heterogene bidimensionnel. Revue de Physique Appliquee 24, 773-777.

O’Regan, W.G., Kourtz, P., Nozaki, S., 1976. Bias in the contagion analog to fire spread. Forest Sci. 22, 61-68.

Ohtsuki, T., Keyes, T., 1986. Biased Percolation: forest fires with wind. J. Phys. A: Mathemat. Gen. 19, L281-L287.

Plotnick, R.E., Gardner, R.H., 1993. Lattices and landscapes.
In: Gardner, R.H. (Ed.), Some Mathematical Questions in Biology: Predicting Spatial Effects in Ecological Systems, vol. 26. American Mathematical Society, Providence, RI, pp. $129-158$.

Renkin, R.A., Despain, D.G., 1991. Fuel moisture, forest type, and lighting caused fire in Yellowstone National Park. Can. J. For. Res. 22, 37-45.

Richards, G.D., 1993. The properties of elliptical wildfire growth for time-dependent fuel and meteorological conditions. Combust. Sci. Technol. 92, 145-171.

Romme, W.H., 1982. Fire and landscape diversity in subalpine forests of Yellowstone National Park. Ecol. Monographs 52, 199-221.

Romme, W.H., Despain, D.G., 1989. Historical perspectives on the Yellowstone fires of 1988. BioScience 39, 695-699.

Rothermel, R.C., 1972. A mathematical model for predicting fire spread in wildland fuels. USDA Forest Service Research Paper INT-115.

Rothermel, R.C., 1983. How to predict the spread and intensity of forest and range fires. USDA Forest Service Technical Report INT-143.

Rothermel, R.C., 1991. Predicting behavior of the 1988 Yellowstone fires: projections versus reality. Int. J. Wildland Fire $1,1-10$.

Stauffer, D., Aharony, A., 1992. Introduction to Percolation Theory. Taylor and Francis, Washington, DC.

Swetnam, T.W., Betancourt, J.L., 1990. Fire-southern oscillation relations in southwestern United States. Science 249, 1017-1020.

Turner, M.C., Dale, V.H., 1991. Modeling landscape disturbance. In: Turner, M.G., Gardner, R.H. (Eds.), Quantitative Methods in Landscape Ecology. Springer, Berlin, pp. 323352.

Turner, M.G., Gardner, R.H., Dale, V.H., O’Neill, R.V., 1989. Predicting the spread of disturbance across heterogeneous landscapes. Oikos 55, 121-129.

Turner, M.G., Romme, W.H., 1994. Landscape dynamics in crown fire ecosystems. Landscape Ecol. 9, 59-77.

Turner, M.G., Gardner, R.H., Romme, W.H., 1994. Landscape disturbance models and the long-term dynamics of natural areas. Natural Areas J. 14, 3-11.

Turner, M.G., Romme, W.H., Gardner, R.H., Hargrove, W.W., 1997. Effects of fire size and pattern on early post-fire succession in subalpine forests of Yellowstone National Park, Wyoming. Ecol. Monogr., in press.

Vasconcelos, M.J., Guertin, D.P., 1992. FIREMAP-simulation of fire growth with a geographic information system. Int. J. Wildland Fire 2, 87-96.

Van Wagner, C.E., 1969. A simple fire-growth model. For. Chron. 45, 103-104.

Van Wagner, C.E., 1977. Conditions for the start and spread of crown fires. Can. J. For. Res. 7, 23-34.

von Niessen, W., Blumen, A., 1988. Dynamic simulation of forest fires. Can. J. For. Res. 18, 805-812.

Zack, J.A., Minnich, R.A., 1991. Integration of geographic information systems with a diagnostic wind field model for fire management. For. Sci. 37, 560-573. 